\section{The Morphology of Filterable Viruses.}

THREE brief papers in the December number of the Journal of the Royal Microscopical Society by J. E. Barnard, J. Smiles, and F. V. Welch, discuss the great difficulties of determining the outward forms of the filterable viruses, and some contribution is made towards improved methods of attack. Mr. Barnard states that all ordinary bacteria may be stained and their size and form demonstrated if they are not less than $0.2 \mu$ in diameter. The virus of bovine pleuropneumonia, which can be definitely and readily grown in artificial media, comes within this limit, but its minute size has precluded any satisfactory knowlerge of its real appearance and of any possible phases through which it may pass in its growth eycle. Staining processes, moreover, have not helped matters.

Mr. Smiles has, by the aid of a dark-ground illuminator and an unstopped oil-immersion objective of 2 mm. focal length and $1 \cdot 20$ N.A., attempted to follow the changes in shape which occur in the virus bodies growing in fluid medium. Drawings of the observed changes are given, and it would appear that, in young culture, grouping of the organism is the chief feature. These groups consist of spherical, aspherical, and granular forms with occasional elliptical and cylindrical masses. These may be so closely apposed to each other as to render difficult the definition of connecting links. Short connecting filaments of low visibility have, however, been detected. As the culture ages, the number of organisms per group diminishes, and finally the culture shows merely single spheres, some with attached granules and some without, and also free granules. Mr. Smiles suggests that in growth the initial spherical form elongates to form the cylindrical type, and this latter breaks up again into two or three small spherical or granular forms. After 48 hours' incubation the cylindrical form may again break up into a chain of four or five granules which finally assume spherical form.

In the course of his work Mr. Smiles has also made use of pleuro-pneumonia cultures grown on thin films of media on ordinary microscopic slips as described by Mr. F. V. Welch. The method employed by him is eminently suitable for the object in view. It should not, however, be described as a new method, but only as one of many modifications of an old and extremely useful method for studying cultural growth in situ both in the fresh and in the fixed and stained condition.

\section{University and Educational Intelligence.}

THE annual conference of the Association of Teachers in Technical Institutions will be held this year at Plymouth on Friday, June 3-Tuesday, June 7. The provisional programme includes, in addition to the business of the Conference, a number of excursions. Arrangements are being made to visit, amongst other places, the Seale Hayne Agricultural College and the Marine Biological Laboratory, Plymouth. An important feature will be an educational and industrial exhibition in the Guildhall on June 4-10.

Applications are invited for the Astley Cooper Studentship at Guy's Hospital, value $£ 150$ per annum, plus an additional sum of $£ 50$ for expenses. The studentship is tenable for three years. By the terms of the will of the founder, the studentship may not be awarded to any member of the staff of Guy's or St. Thomas's Hospitals, or to any one related by blood or affinity to them. Particulars may be obtained from Mr. C. H. Fagge, Guy's Hospital, S.E.1.
The latest date for the receipt of applications for the studentship is May 31 .

The Charles Lathrop Pack Forestry Trust, founded by Mr. Charles Lathrop Pack, president of the American Tree Association, has given 130,000 dollars for the endowment of a research professorship in forest soils in Cornell University. Generous provision has also been made for the expenses of the advanced investigations to be undertaken, which will be done in the New York State College of Agriculture. The proposed work is a new development in forest research in the United States. Mr. Pack has made other large gifts for the promotion and support of education in forestry. Recently announcement was made concerning the Charles Lathrop Pack Demonstration Forest, 2500 acres of white-pine land on the main Adirondack highway near Lake George; and he has given land or endowments to other American forestry schools, including the New York State College of Forestry, the Yale Forest School, and the University of Washington.

The fifth Pan-American Child Congress is to be held at Havana in Cuba with the official support of the Government. Owing to difficulties arising from the hurricane the date has been postponed until December 1927. An international exhibition on child hygiene will be held in connexion with the meeting. The Congress will be divided into six sections, dealing with medicine, hygiene, sociology, education, psychology and legislation, and the languages admitted will be Spanish, English, Portuguese, and French. There will be two governmental sessions, for official delegates only; at these, resolutions prepared by the committee will be put to the vote. A draft programme has been prepared with twelve leading topics for each section. As compared with other educational conferences it is interesting to note the great stress on the medical aspects of our problems. The Secretary-General is Dr. Felix Hurtado, Circulo Medico (Malecon 15), Habana. Some information in English typescript has also been circulated by the Commissioner of Educa. tion, United States Department of the Interior, Bureau of Education, Washington.

After an experimental period of five years, a record of which is given in the Report of the Central Scholarships Committee of the Ministry of Agriculture and Fisheries (London: H.M.S.O.), the Government has decided to continue the awards of scholarships for the sons and daughters of agricultural workers under a slightly modified scheme. Junior scholarships are provided for short courses in agriculture, horticulture, dairying or poultry-keeping at farm institutes, while senior scholarships are intended for diploma or degree courses in agricultural, veterinary, or allied sciences at universities or appropriate colleges. The senior grade is normally reached after passing through the junior grade, but certain exceptions may be made. All scholarships will allow of attendance at the courses free of cost to the parents. Candidates must be either bona fide workers in agriculture or sons or daughters of agricultural or rural workmen, or of working bailiffs and smallholders whose means are comparable with those of agricultural workmen. Provided that a sufficient number of suitable applications are received, about one hundred and twenty junior, ten extended junior, and ten senior scholarships will be awarded this year. Forms of application, to be returned before April 30, and full particulars may be obtained from the Secretary, Ministry of Agriculture and Fisheries, 10 Whitehall Place, London, S.W.1, or locally from the offices of County Councils.

No. 2998, VoL. 119] 